\title{
Antiproliferative Effects of Oxytocin and Desmopressin on Canine Mammary Cancer Cells
}

\author{
Micaela Andrea Benavente ${ }^{1 *}$, Carolina Paula Bianchi ${ }^{1}$, Fernanda Imperiale ${ }^{2}$ and \\ Marcelo Alfredo Aba ${ }^{1}$ \\ ${ }^{1}$ Laboratorio de Endocrinología, Centro de Investigación Veterinaria de Tandil (CIVETAN), CONICET, Facultad de Ciencias \\ Veterinarias, Universidad Nacional del Centro de la Provincia de Buenos Aires (UNCPBA), Tandil, Argentina, ${ }^{2}$ Laboratorio de \\ Farmacología, Centro de Investigación Veterinaria de Tandil (CIVETAN), CONICET, Facultad de Ciencias Veterinarias, \\ Universidad Nacional del Centro de la Provincia de Buenos Aires (UNCPBA), Tandil, Argentina
}

OPEN ACCESS

Edited by:

Laura Pena,

Complutense University of Madrid,

Spain

Reviewed by:

Francisco Ruben Carvallo, University of California Davis, USA

Elspeth Milne,

University of Edinburgh, UK

${ }^{*}$ Correspondence:

Micaela Andrea Benavente micaela@vet.unicen.edu.ar

Specialty section:

This article was submitted to Veterinary Experimental and

Diagnostic Pathology,

a section of the journal

Frontiers in Veterinary Science

Received: 28 August 2016 Accepted: 14 December 2016 Published: 26 December 2016

Citation:

Benavente MA, Bianchi CP, Imperiale F and Aba MA (2016) Antiproliferative Effects of Oxytocin and Desmopressin on Canine

Mammary Cancer Cells.

Front. Vet. Sci. 3:119. doi: 10.3389/fvets.2016.00119
Neoplasms of the mammary gland represent the most frequent tumor type in the female dog, and according to the histologic criteria, approximately $50 \%$ of them are malignant. In the most aggressive cases of mammary cancer, surgery is not enough to warrant a favorable outcome, and adjuvant therapies are needed to improve the patient's overall survival. The aim of the present study was to evaluate the effects of two peptides on proliferation of a canine mammary cancer cell line derived from a simple carcinoma. The cell line CMT-U27 was grown in 96-well plates, at two cell densities $\left(4 \times 10^{3}\right.$ and $8 \times 10^{3}$ cells/well). Cultures were treated with oxytocin (OT) or desmopressin at five concentrations $(10,50,100,500$, and $1000 \mathrm{nM})$. After $72 \mathrm{~h}$ of incubation, cell proliferation was determined by the MTT assay. Results showed that with $4 \times 10^{3}$ cells/well, OT at 50, 500 , and $1000 \mathrm{nM}$ was growth inhibitory for the cells, being statistically significant at $1000 \mathrm{nM}$. On the contrary, no antiproliferative effect was observed with 10 or $100 \mathrm{nM}$. At $8 \times 10^{3}$ cells/well, OT showed a significant antiproliferative effect only with the highest concentration (1000 nM). Desmopressin at $4 \times 10^{3}$ cells/well decreased cell viability at concentrations of $50,100,500$, and $1000 \mathrm{nM}$ (statistically significant with the highest concentration), while no effect was observed with $10 \mathrm{nM}$. With $8 \times 10^{3}$ cells/well, this peptide reduced cell growth at 100,500, and $1000 \mathrm{nM}$. In conclusion, we suggest that these peptides may be potential and promising compounds for the treatment of dogs with simple carcinomas of the mammary gland. In vivo studies are required to confirm this hypothesis.

Keywords: mammary gland tumors, canines, cell line, oxytocin, desmopressin

\section{INTRODUCTION}

Mammary gland tumors are the most common neoplasms in intact female dogs, and approximately $50 \%$ of them are malignant. The treatment of choice for mammary gland tumors is surgical excision. However, in malignant cases, surgery alone is not enough to warrant a favorable outcome, and adjuvant therapies are needed to reduce the risk of recurrence or metastasis $(1,2)$. In women with aggressive breast cancer, postoperative chemotherapy is routinely administered to improve disease free and overall survival rates (3). In bitches, although several chemotherapy protocols have been 
tested (4-6), most of them did not show real benefits in survival time or have high toxicity and side effects. A recent study has described a longer overall survival in dogs treated with surgery and carboplatin, than those treated with surgery alone, indicating that this chemotherapeutic agent may be beneficial for the treatment of malignant mammary tumors (7).

Hormonal therapy is a well-established adjuvant treatment for women with estrogen receptor-positive tumors (hormonedependent breast cancer), and tamoxifen is one of the antiestrogens most commonly used (8). However, the use of tamoxifen is restricted in female dogs due to its side effects, which includes vulvar swelling, vulvar discharge, and pyometra, among others (9). Therefore, it is essential to concentrate on the development of safe and effective adjuvant treatments for dogs with mammary cancer, in order to reduce the risk of recurrence or metastasis.

A number of in vitro studies performed on murine and human cancer cells have suggested that some peptide hormones can modulate tumor growth (10-12), by interacting with its membrane receptors. However, little is known about the effects of these peptides on canine mammary cancer.

Oxytocin (OT) is a peptide hormone mainly synthetized in the hypothalamus, which plays a key role in uterine contraction and milk ejection, among other functions (13). However, in recent years, a new role for OT has been described in relation to the carcinogenic process. Several studies have demonstrated that OT could stimulate, inhibit, or have no effect on neoplastic cell growth, and these diverse effects seem to be mediated by different signaling pathways. In neoplastic cells derived from trophoblast and endothelium, OT was found to promote cell proliferation (14, 15). On the contrary, in human neoplastic cells of mammary (16), nervous (17), and bone origin (18), OT inhibited the cell growth. Moreover, in vivo experiments showed that the subcutaneous administration of OT in Balb-c mice bearing breast carcinomas can reduce tumor growth (19). In addition, the presence of OT receptors has been described, both in human primary breast carcinomas and cell lines (20). According to these findings, OT appears to be involved in mammary tumor growth. To our knowledge, there is only one report about the effects of OT on the proliferation of canine mammary cancer cells.

Desmopressin [1-d-amino-8-D-arginine vasopressin (DDAVP)] is a synthetic analog of the antidiuretic hormone vasopressin, which has been used in humans and dogs for the management of diabetes insipidus (21). In addition, DDAVP has various effects in the hemostatic system, causing the release of coagulation factors VIII and von Willebrand (22). Due to its hemostatic properties, DDAVP has also been used in patients with different bleeding disorders (23). Interestingly, in a mouse model of breast cancer, DDAVP inhibited lung colonization by neoplastic cells (24). Since then, a number of studies have shown that this peptide seems to have antimetastatic and antiproliferative effects, both in mouse models of breast cancer and in different breast cancer cell lines $(25,26)$. Furthermore, a veterinary clinical trial has demonstrated that the perioperative administration of DDAVP increases the disease free and overall survival time in surgically treated bitches with mammary cancer of various histological types (27). Considering all these information, DDAVP could represent an excellent compound for surgical adjuvant therapy for the management of bitches with malignant mammary tumors.

The aim of the present study was to investigate the effects of OT and desmopressin on the proliferation of a canine mammary carcinoma cell line.

\section{MATERIALS AND METHODS}

\section{Tumor Cell Line}

The canine mammary tumor cell line CMT-U27 was used in this study, which was generously supplied by Prof. Eva Hellmén. This cell line was established from a simple ductal carcinoma at the Swedish University of Agricultural Sciences (SLU) in Sweden (28). In previous studies, CMT-U27 cells have shown a high growth rate and antiapoptotic potential (29).

\section{Cell Culture Conditions}

CMT-U27 cells were routinely cultivated in RPMI-1640 medium (Sigma-Aldrich) supplemented with $10 \%$ fetal bovine serum (FBS) (Natocor, Argentina), $100 \mathrm{UI} / \mathrm{ml}$ penicillin and $100 \mu \mathrm{g} /$ $\mathrm{ml}$ streptomycin (Sigma-Aldrich). Cells were cultured in $25 \mathrm{~cm}^{2}$ cell culture plastic flasks (Corning Inc., USA) in a humidified incubator (Panasonic, Lobov Científica, Argentina) with 5\% $\mathrm{CO}_{2}$ at $37^{\circ} \mathrm{C}$.

\section{Peptides}

Oxytocin was supplied by Chemo Romikin S.A. (Buenos Aires, Argentina) and desmopressin (Elea Laboratories, Argentina) was kindly provided by Dr. Daniel Alonso, from Laboratory of Molecular Oncology, Quilmes National University (Buenos Aires, Argentina). Both peptides were supplied in the lyophilized form, and at the beginning of the assays they were dissolved in sterile phosphate buffer saline (PBS) $\mathrm{pH} 7.4$ at a final concentration of $100 \mu \mathrm{M}$, and then aliquots were stored at $-20^{\circ} \mathrm{C}$ for no more than 1 month.

\section{Cell Proliferation Assay}

Cell viability was measured using the MTT (3-(4,5-dimethylthiazol-2-yl)-2,5-diphenyltetrazolium bromide) colorimetric dye reduction method, as previously reported $(26,30)$. The medium was removed from the flasks, cells were washed with $3 \mathrm{ml}$ of sterile PBS and then detached using EDTA for 5 min. Cell number was determined using a hemocytometer. Then, CMT-U27 cells were seeded into 96-well plates at two densities $\left(4 \times 10^{3}\right.$ and $8 \times 10^{3}$ cells/well) in $200 \mu \mathrm{l}$ of RPMI-1640 supplemented with $10 \%$ (v/v) FBS and incubated in a humidified atmosphere at $37^{\circ} \mathrm{C}$ under $5 \%$ $\mathrm{CO}_{2}$ and $95 \%$ air to allow cell adhesion. After overnight culture, the medium was removed and replaced with $200 \mu \mathrm{l}$ of medium containing OT or DDAVP at five concentrations: 10, 50, 100, 500, and $1000 \mathrm{nM}$, or medium without drugs (controls). The cells were incubated for $72 \mathrm{~h}$. Afterward, MTT (Sigma-Aldrich) $(20 \mu \mathrm{l})$ was added to each well and incubated for $2 \mathrm{~h}$ at $37^{\circ} \mathrm{C}$ to allow MTT to form formazan crystals by reacting with metabolically active cells. To complete solubilization of the formazan crystals, $100 \mu \mathrm{l}$ of isopropanol were immediately added to each well. Cell viability was quantified by measuring the absorbance at $595 \mathrm{~nm}$ in 


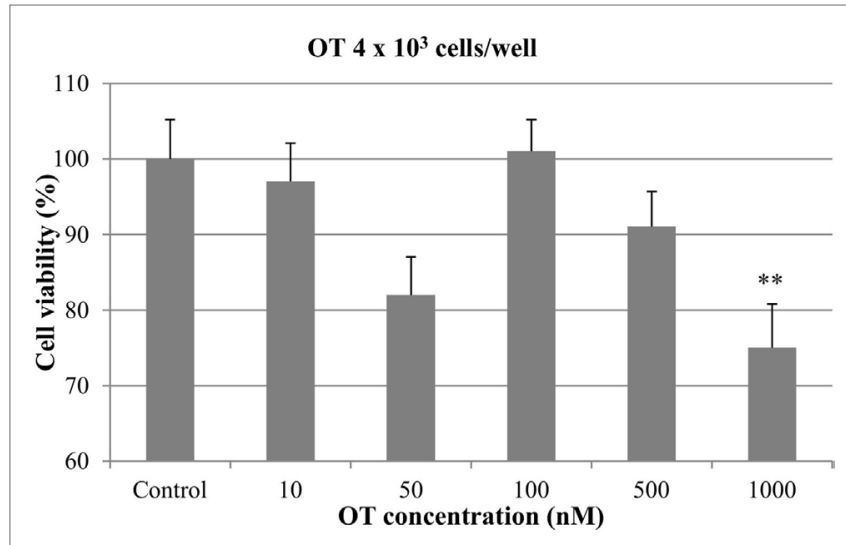

FIGURE 1 | Effect of oxytocin (OT) on in vitro growth of canine mammary cancer cells. CMT-U27 cells were grown in 96-well plates ( $4 \times 10^{3}$ cells/well) with appropriate concentrations of OT. MTT assay was performed after $\left.72 \mathrm{~h} .{ }^{* *}\right)$ Indicates values statistically different from the control group $(p<0.01)$. Values represent means $\pm \Sigma E$ from 12 replicate measurements from four independent experiments.

a multi-well plate reader (Beckman Coulter, DTX 880 Multimode Detector). All the samples were examined in triplicate, and each experiment was conducted four times. The optical density of formazan formed in untreated control cells was considered as $100 \%$ viability. The optical densities from the treated cells were converted to a percentage of living cells against the control.

\section{Statistical Analyses}

Data from the four independent experiments was analyzed by one-way analysis of variance contrasted with Dunnett Multiple Comparisons Test at a significance level of $p<0.05$. The values were evaluated for approximate normality of distribution by the Kolmogorov-Smirnov test.

\section{RESULTS}

\section{Effect of OT on Canine Mammary Cancer Cells}

At $4 \times 10^{3}$ cells/well, a decrease in cell growth was observed with OT at concentrations of 50,500, and $1000 \mathrm{nM}$. However, the inhibitory effect was statistically significant only with the highest concentration of the hormone $(p<0.01)$, which resulted in a $25 \%$ of inhibition of cell viability. OT did not affect the proliferation of CMT-U27 cells at 10 and $100 \mathrm{nM}$ (Figure 1).

Regarding the experiments with $8 \times 10^{3}$ cells/well, no significant antiproliferative effect was obtained with OT at 10, 50, 100 , and $500 \mathrm{nM}$. On the contrary, the highest concentration of OT (1000 nM) caused a significant inhibition of CMT-U27 cell growth (almost 25\%) $(p<0.05)$ (Figure 2).

\section{Effect of Desmopressin on Canine Mammary Cancer Cells}

At $4 \times 10^{3}$ cells/well, DDAVP at concentration of $1000 \mathrm{nM}$ resulted in a significant antiproliferative effect $(22 \%)(p<0.05)$.
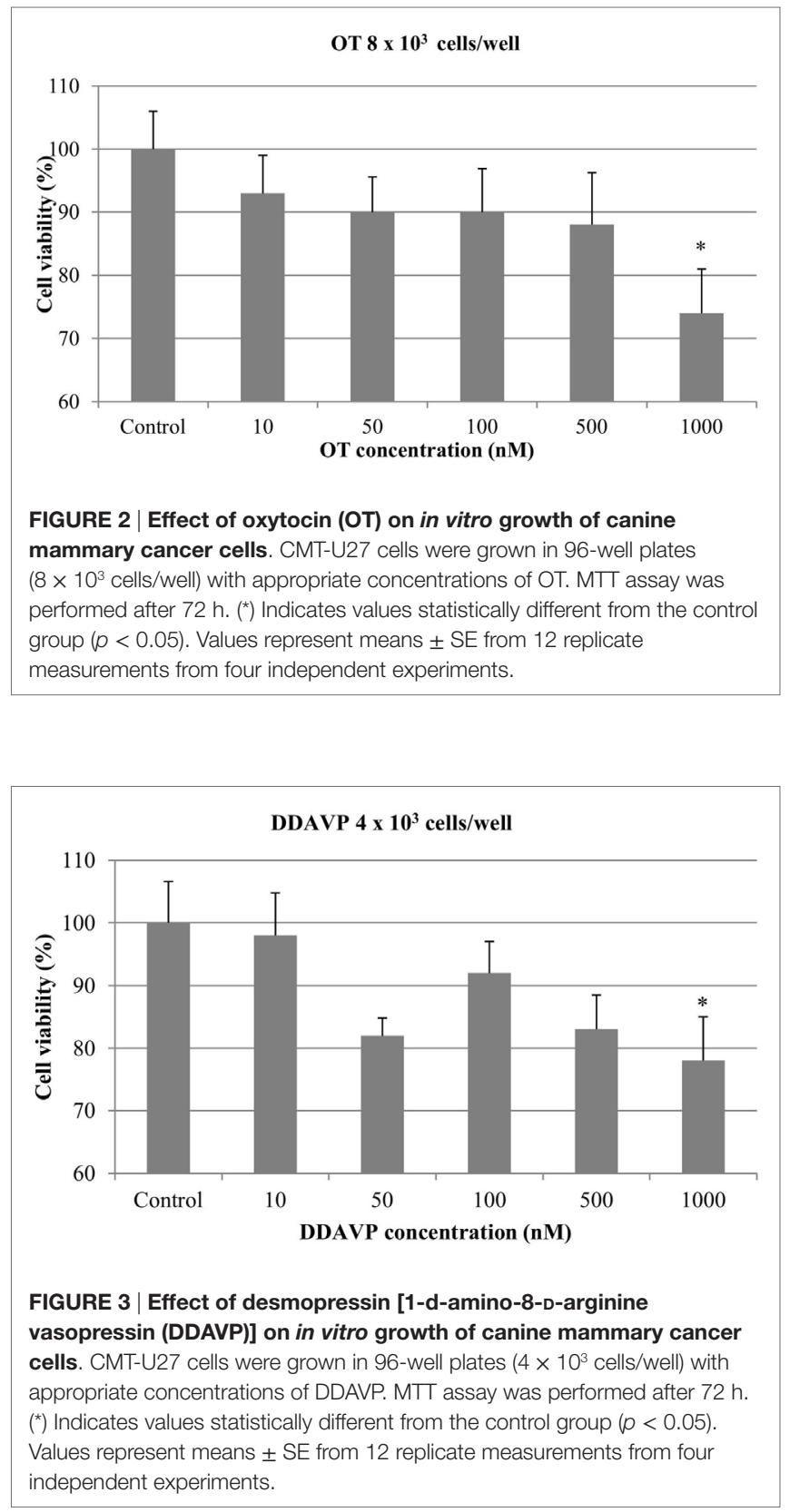

The growth of mammary cancer cells was not affected by the addition of DDAVP at 10, 50, 100, and $500 \mathrm{nM}$ (Figure 3).

At $8 \times 10^{3}$ cells/well, nearly $15 \%$ of cell growth inhibition was obtained with DDAVP at 100, 500, and $1000 \mathrm{nM}$. However, this difference was not statistically significant $(p>0.05)$. DDAVP at 10 and $50 \mathrm{nM}$ did not show any significant effect on cell growth (Figure 4).

\section{DISCUSSION}

This study provides information about the effects of two peptides on in vitro growth of a canine mammary simple carcinoma cell line. The present results show that treatment of 


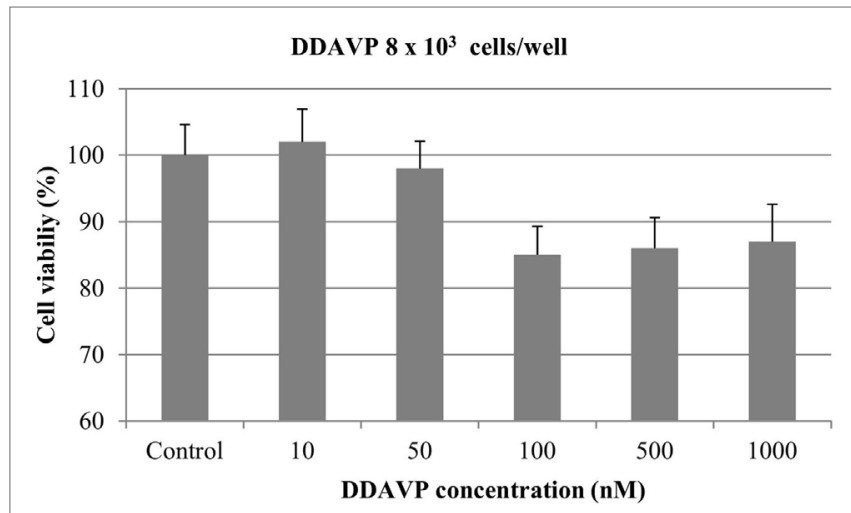

FIGURE 4 | Effect of desmopressin [1-d-amino-8-D-arginine vasopressin (DDAVP)] on in vitro growth of canine mammary cancer cells. CMT-U27 cells were grown in 96 -well plates $\left(8 \times 10^{3}\right.$ cells/well) with appropriate concentrations of DDAVP. MTT assay was performed after $72 \mathrm{~h}$. Values represent means \pm SE from 12 replicate measurements from four independent experiments.

CMT-U27 cells with OT and DDAVP inhibited the proliferation of tumor cells.

As stated before, this canine cell line was isolated from a simple carcinoma, a histological subtype frequently diagnosed in female dogs, and associated with a short disease-free period after surgery (31). In previous studies, CMT-U27 cells showed to be sensitive to antiprogestins (32) and also to cyclooxygenase inhibitors and doxorubicin (33). For this reason, this cell line seems to be a useful in vitro model to evaluate the effects of potential anticancer drugs.

To our knowledge, only one study reports on the effects of OT on this canine mammary cancer cell line, where a decrease in cell proliferation was observed at $1000 \mathrm{nM}$ concentration, although this result was not consistent in all the assays performed (34). The author attributes these variations to different aspects of the cell line, including the stage of the cell cycle in which the cells were at the beginning of each assay, the moment in which the cells were last reseeded before the assay, or when the cell culture medium was changed in relation to the assay. Besides, this last study reported inhibitory effect with OT $100 \mathrm{nM}$. In the present study, a growth inhibitory effect with OT at $1000 \mathrm{nM}$ was detected in all the assays, while no significant effect was observed at $100 \mathrm{nM}$. Both studies on canines are in agreement with experiments on human breast cancer cell lines, who reported the inhibitory effect of OT, even with minimum doses of $1 \mathrm{nM}$ of OT (35). A more recent study demonstrated that both normal myoepithelial cells and breast carcinomas cell lines can synthesize OT and that estrogens can modulate this synthesis (36). Additional studies on CMT-U27 cells could include the evaluation of OT synthesis by the canine cancer cells and the effects of estrogens or progesterone on OT action.

This is the first report where the effects of desmopressin are evaluated on cultures of canine mammary cancer cells. When the cells were treated with increasing concentrations of DDAVP, a cell growth inhibition was observed. Previously, a study demonstrated a beneficial effect of perioperative administration of DDAVP (administered at doses of $1 \mu \mathrm{g} / \mathrm{kg}, 30 \mathrm{~min}$ before and $24 \mathrm{~h}$ after surgery) on survival in bitches with mammary cancer, without causing side effects (27). The results obtained in the present study seem to support the hypothesis that DDAVP can inhibit the growth of residual malignant cells, thus limiting tumor progression. More recently, a phase II dose-escalation trial in women with breast cancer was performed, demonstrating that DDAVP, administered 30-60 min before and $24 \mathrm{~h}$ after surgical resection, reduced intraoperative bleeding and the number of circulating tumor cells. Moreover, it appeared to be safe and well tolerated at the highest dose level evaluated $(2 \mu \mathrm{g} / \mathrm{kg})(37)$.

The in vitro results of the present study are in agreement with those of other studies that have shown that the addition of DDAVP to mouse and human mammary cancer cells inhibits cell proliferation $(38,39)$. The antiproliferative action of DDAVP appears to be mediated trough the $\mathrm{V}_{2}$ vasopressin receptor, which involves the increase of intracellular cAMP concentrations (22). The presence of $\mathrm{V}_{2}$ vasopressin receptors has been demonstrated in the MCF-7 human breast cancer cell line (40). More recently, the novel $\left[\mathrm{V}^{4} \mathrm{Q}^{5}\right]$ DDAVP analog has been synthesized and assayed in cultures of MCF-7, causing a significantly greater inhibition of cell proliferation than DDAVP, at concentrations of $500 \mathrm{nM}$ or higher (26). Additional studies are necessary to investigate the presence of the $V_{2}$ vasopressin receptor on canine mammary cancer cell lines and spontaneous mammary tumors and to evaluate the effects of the analog $\left[\mathrm{V}^{4} \mathrm{Q}^{5}\right] \mathrm{dDAVP}$ on in vitro growth of canine mammary cancer cells.

Besides, our experiments showed that at the lower cell density $\left(4 \times 10^{3}\right.$ cells/well), both OT and DDAVP $50 \mathrm{nM}$ exhibited an antiproliferative effect similar to that obtained with $1000 \mathrm{nM}$ (approximately 20\%). Likewise, a biphasic pattern, observed at low cell density, has been reported recently on human prostate cancer cell lines treated with desmopressin, where low doses $(1 \mathrm{nM})$ as well as a higher dose $(1 \mu \mathrm{M})$ have an antiproliferative effect (41). This "biphasic effect" of peptides was shown some decades ago with OT on human uterus and oviduct (42). Afterward, this effect was described for other molecules in detail in 1977 (43). This biphasic dose response seems to occur when a single agonist has differential affinities for two opposite receptor subtypes, leading to different signaling pathways. Due to the fact that only one OT receptor is known, some authors have suggested that in some tissues and under particular circumstances, OT action could be mediated by vasopressin receptors, for which OT maintains a certain affinity (44).

To conclude, the present study shows that OT and desmopressin inhibit the proliferation of the canine mammary cancer cell line CMT-U27, by almost $20 \%$ with the highest concentration $(1000 \mathrm{nM})$. Further studies on this and other canine mammary cell lines are needed to evaluate its potential as antitumor agents, alone or combined with conventional cytotoxic drugs, in the treatment of dogs with advanced mammary carcinomas.

\section{AUTHOR CONTRIBUTIONS}

MB: study design, conducted laboratory work, data collection and analysis, and drafting the manuscript. CB: study design, data 
analysis, and critical review of the manuscript. FI: conducted laboratory work and critical review of the manuscript. MA: study design and coordination, data analysis, drafting, and review of the manuscript.

\section{REFERENCES}

1. Lana S, Rutteman G, Withrow S. Tumors of the mammary gland. In: Withrow SJ, Vail DM, editors. Withrow and MacEwen's Small Animal Clinical Oncology. St. Louis, MO: Sounders Elsevier Inc (2007). p. 620-37.

2. Misdorp W. Tumors of the mammary gland. 4th ed. In: Meuten DJ, editor. Tumors in Domestic Animals. Ames, IW: Blackwell Publishing Company (2002). p. 575-606.

3. Hortobagyi GN. Progress in systemic chemotherapy of primary breast cancer: an overview. JNCI Monogr (2001) 30:72-9. doi:10.1093/oxfordjournals. jncimonographs.a003465

4. Karayannopoulou M, Kaldrymidou E, Constantinidis TC, Dessiris A. Adjuvant post-operative chemotherapy in bitches with mammary cancer. J Vet Med A Physiol Pathol Clin Med (2001) 48(2):85-96. doi:10.1046/j.1439-0442.2001. 00336.x

5. Simon D, Schoenrock D, Baumgärtner W, Nolte I. Postoperative adjuvant treatment of invasive malignant mammary gland tumors in dogs with doxorubicin and docetaxel. J Vet Intern Med (2006) 20:1184-90. doi:10.1111/ j.1939-1676.2006.tb00720.x

6. Clemente M, De Andres PJ, Peña L, Perez-Alenza MD. Survival time of dogs with inflammatory mammary cancer treated with palliative therapy alone or palliative therapy plus chemotherapy. Vet Rec (2009) 165:78-81. doi:10.1136/ vetrec.165.3.78

7. Lavalle GE, De Campos CB, Bertagnolli AC, Cassali GD. Canine malignant mammary gland neoplasms with advanced clinical staging treated with carboplatin and cyclooxygenase inhibitors. In Vivo (2012) 26(3):375-9.

8. Platet N, Cathiard AM, Gleizes M, Garcia M. Estrogens and their receptors in breast cancer progression: a dual role in cancer proliferation and invasion. Crit Rev Oncol Hematol (2004) 51:55-67. doi:10.1016/j.critrevonc.2004. 02.001

9. Tavares WLF, Lavalle GE, Figueiredo MS, Souza AG, Bertagnolli AC, Viana FAB, et al. Evaluation of adverse effects in tamoxifen exposed healthy female dogs. Acta Vet Scand (2010) 52(1):67. doi:10.1186/1751-0147-52-67

10. Guillon G, Kirk CJ, Balestre MN. Characterization of specific V1a vasopressin-binding sites on a rat mammary-tumour-cell line. Biochem J (1986) 240(1):189-96. doi:10.1042/bj2400189

11. Taylor AH, Ang VTY, Jenkins JS, Silverlight JJ, Coombes RC, Luqmani YA. Interaction of vasopressin and oxytocin with human breast carcinoma cells. Cancer Res (1990) 50:7882-6.

12. Sethi T, Langdon S, Smyth J, Rozengurt E. Growth of small cell lung cancer cells: stimulation by multiple neuropeptides and inhibition by broad spectrum antagonists in vitro and in vivo. Cancer Res (1992) 57:2737-43.

13. Geddes DT. Inside the lactating breast: the latest anatomy research. J Midwifery Womens Health (2007) 52(6):556-63. doi:10.1016/j.jmwh.2007.05.004

14. Cassoni P, Sapino A, Munaron L, Deaglio S, Chini B, Graziani A, et al. Activation of functional oxytocin receptors stimulates cell proliferation in human trophoblast and choriocarcinoma cell lines. Endocrinology (2001) 142(3):1130-6. doi:10.1210/endo.142.3.8047

15. Cassoni P, Marrocco T, Bussolati B, Allia E, Munaron L, Sapino A, et al. Oxytocin induces proliferation and migration in immortalized human dermal microvascular endothelial cells and human breast tumor-derived endothelial cells. Mol Cancer Res (2006) 4(6):351-9. doi:10.1158/1541-7786. MCR-06-0024

16. Cassoni P, Sapino A, Fortunati N, Munaron L, Chini B, Bussolati G. Oxytocin inhibits the proliferation of MDA-MB231 human breast-cancer cells via cyclic adenosine monophosphate and protein kinase A. Int J Cancer (1997) 72:340-4. doi:10.1002/(SICI)1097-0215(19970717)72:2<340::AID-IJC23>3.0.CO;2-I

17. Cassoni P, Sapino A, Stella A, Fortunati N, Bussolati G. Presence and significance of oxytocin receptors in human neuroblastomas and glial tumors. Int J Cancer (1998) 77(5):695-700. doi:10.1002/(SICI)1097-0215(19980831) 77:5<695::AID-IJC6>3.0.CO;2-Q

\section{ACKNOWLEDGMENTS}

We thank Prof. Eva Hellmén for supplying the cell line CMT-U27. No specific funding source was involved in this study.

18. Novak JF, Judkins MB, Chernin MI, Cassoni P, Bussolati G, Nitche JA, et al. A plasmin-derived hexapeptide from the carboxyl end of osteocalcin counteracts oxytocin-mediated growth inhibition of osteosarcoma cells. Cancer Res (2000) 60(13):3470-6.

19. Cassoni P, Sapino A, Papotti M, Bussolati G. Oxytocin and oxytocin analogue F314 inhibit cell proliferation and tumor growth of rat and mouse mammary carcinomas. Int J Cancer (1996) 66:817-20. doi:10.1002/ (SICI)1097-0215(19960611)66:6<817::AID-IJC18>3.0.CO;2-\#

20. Bussolati G, Cassoni P, Ghisolfi G, Negro F, Sapino A. Immunolocalization and gene expression of oxytocin receptors in carcinomas and non-neoplastic tissues of the breast. Am J Pathol (1996) 148(6):1895-903.

21. Vande Walle J, Stockner M, Raes A, Nørgaard JP. Desmopressin 30 years in clinical use: a safety review. Curr Drug Saf (2007) 2(3):232-8. doi:10.2174/157488607781668891

22. Kaufmann JE, Vischer UM. Cellular mechanisms of the hemostatic effects of desmopressin (DDAVP). J Thromb Haemost (2003) 1(4):682-9. doi:10.1046/j.1538-7836.2003.00190.x

23. Mannucci P. Desmopressin (DDAVP) in the treatment of bleeding disorders: the first 20 years. Blood (1997) 90(4):2515-21.

24. Alonso DF, Skilton G, Farías EF, Bal de Kier Joffé E, Gomez DE. Antimetastatic effect of desmopressin in a mouse mammary tumor model. Breast Cancer Res Treat (1999) 57(3):271-5. doi:10.1023/A:1006291607871

25. Giron S, Tejera AM, Ripoll GV, Gomez DE, Alonso DF. Desmopressin inhibits lung and lymph node metastasis in a mouse mammary carcinoma model of surgical manipulation. J Surg Oncol (2002) 81(1):38-44. doi:10.1002/jso.10141

26. Iannucci NB, Ripoll GV, Garona J, Cascone O, Ciccia GN, Gomez DE, et al. Antiproliferative effect of 1-deamino-8-D-arginine vasopressin analogs on human breast cancer cells. Future Med Chem (2011) 3(16):1987-93. doi:10.4155/fmc.11.152

27. Hermo GA, Torres P, Ripoll GV, Scursoni AM, Gomez DE, Alonso DF, et al. Perioperative desmopressin prolongs survival in surgically treated bitches with mammary gland tumours: a pilot study. Vet J (2008) 178(1):103-8. doi:10.1016/j.tvjl.2007.06.015

28. Hellmen E. Characterization of four in vitro established canine mammary carcinomas and one atypical benign mixed tumor cell lines. Vitr Cell Dev Biol (1992) 28(5):309-19. doi:10.1007/BF02877054

29. Krol M, Pawlowski KM, Skierski J, Rao NAS, Hellmen E, Mol JA, et al. Transcriptomic profile of two canine mammary cancer cell lines with different proliferative and anti-apoptotic potential. J Physiol Pharmacol (2009) 60(1):95-106.

30. Majchrzak K, Re Lo D, Gajewska M, Bulkowska M, Homa A, Motyl T, et al. Migrastatin analogues inhibit canine mammary cancer cell migration and invasion. PLoS One (2013) 8:e76789. doi:10.1371/journal.pone.0076789

31. Martín de las Mulas J, Millán Y, Dios R. A prospective analysis of immunohistochemically determined estrogen receptor $\alpha$ and progesterone receptor expression and host and tumor factors as predictors of disease-free period in mammary tumors of the dog. Vet Pathol (2005) 42:200-12. doi:10.1354/ vp.42-2-200

32. Guil-luna S, Hellmén E, Sánchez-céspedes R, Millán Y, Martín de las Mulas J. The antiprogestins mifepristone and onapristone reduce cell proliferation in the canine mammary carcinoma cell line CMT-U27. Histol Histopathol (2014) 29:949-55. doi:10.14670/HH-29.949

33. Bakirel T, Alkan FÜ, Üstüner O, Çinar S, Yildirim F, Erten G, et al. Synergistic growth inhibitory effect of deracoxib with doxorubicin against a canine mammary tumor cell line, CMT-U27. J Vet Med Sci (2016) 78:657-68. doi:10.1292/ jvms.15-0387

34. Bergman I. The Significance of Oxytocin in Canine Mammary Tumours. Master thesis. Swedish University of Agricultural Sciences, Uppsala (2012).

35. Cassoni P, Sapino A, Negro F, Bussolati G. Oxytocin inhibits proliferation of human breast cancer cell lines. Virchows Arch (1994) 425(5):467-72. doi:10.1007/BF00197549 
36. Cassoni P, Marrocco T, Sapino A, Allia E, Bussolati G. Oxytocin synthesis within the normal and neoplastic breast: first evidence of a local peptide source. Int J Oncol (2006) 28(5):1263-8.

37. Weinberg RS, Grecco MO, Ferro GS, Seigelshifer DJ, Perroni NV, Terrier FJ, et al. A phase II dose-escalation trial of perioperative desmopressin (1-desamino-8-D-arginine vasopressin) in breast cancer patients. Springerplus (2015) 19(4):428. doi:10.1186/s40064-015-1217-y

38. Alonso DF, Skilton G, Farina H, De Lorenzo M, Gomez D. Modulation of growth and urokinase secretion by vasopressin and closely related nonapeptides in metastatic mouse mammary tumor cells. Int J Oncol (1997) 10:375-9.

39. Keegan BP, Akerman BL, Péqueux C, North WG. Provasopressin expression by breast cancer cells: implications for growth and novel treatment strategies. Breast Cancer Res Treat (2006) 95:265-77. doi:10.1007/s10549-005-9024-8

40. North WG, Fay MJ, Du J. MCF-7 breast cancer cells express normal forms of all vasopressin receptors plus an abnormal V2R. Peptides (1999) 20(7):837-42. doi:10.1016/S0196-9781(99)00070-4

41. Sasaki H, Klotz LH, Sugar LM, Kiss A, Venkateswaran V. A combination of desmopressin and docetaxel inhibit cell proliferation and invasion mediated by urokinase-type plasminogen activator (uPA) in human prostate cancer cells. Biochem Biophys Res Commun (2015) 464(3):848-54. doi:10.1016/ j.bbrc.2015.07.050
42. Nakanishi H, Wood C. Biphasic effects of oxytocin on human uterine and tube motility. Aus N Z J Obstet Gynaec (1968) 8:181-8. doi:10.1111/ j.1479-828X.1968.tb00711.x

43. Szabadi E. A model of two functionally antagonistic receptor populations activated by the same agonist. J Theor Biol (1977) 69:101-12. doi:10.1016/0022-5193(77)90390-3

44. Fay MJJ, Longo KA, North WG. Oxytocin does not induce a rise in intracellular free calcium in human breast cancer cells. Res Comun Mol Pathol Pharmacol (1999) 103:115-28.

Conflict of Interest Statement: The authors declare that the research was conducted in the absence of any commercial or financial relationships that could be construed as a potential conflict of interest.

Copyright (C) 2016 Benavente, Bianchi, Imperiale and Aba. This is an open-access article distributed under the terms of the Creative Commons Attribution License (CC BY). The use, distribution or reproduction in other forums is permitted, provided the original author(s) or licensor are credited and that the original publication in this journal is cited, in accordance with accepted academic practice. No use, distribution or reproduction is permitted which does not comply with these terms. 